\title{
Sinking or Not? An Indonesian Approach to Prevent the Rise of Sea Levels due to Global Warming
}

\author{
Iin Karita Sakharina \& Farida Patittingi \& \\ Hamzah Halim \& Marthen Napang \& Juajir Sumardi \& \\ Andi Bau' Inggit \& Marcel Hendrapati*
}

\begin{abstract}
Global warming, or climate change, could be the main reason why small islands in many areas of the Earth, including those in Indonesian territory, are sinking. Many small Indonesian islands are between 1 and 3 metres under the surface of the sea because of raised sea levels caused by climate change. If this situation continues, it would affect many of the outermost islands of Indonesia, so that we should anticipate the danger that the outermost islands would be submerged. The basepoints and archipelagic baselines would then be replaced, among other serious consequences for Indonesia. The Paris Climate Agreement, signed by almost 200 states in 2015, is the main instrument for mitigating global warming through reducing the emission of greenhouse gases. Indonesia ratified the Paris Climate Agreement, because it has a great interest in mitigating the phenomenon that is causing the sea level to rise, which is having a serious impact on its islands.
\end{abstract}

\section{Keywords}

Global Warming, Climate Change, Greenhouse Effect, Outermost Islands, Basepoints, Archipelagic Baselines

* All the authors are lecturers at the Law Faculty of Hasanuddin University, Republic of Indonesia. Corresponding author: Marcel Hendrapati. He may be contacted at: mhendrapati@yahoo.com / Address: Kompleks Taman Toraja, Jalan Danau Toba No.8, Makassar, 90224, South Sulawesi Province, Republic of Indonesia.

All the websites cited in this article were last visited on April 23, 2020. 


\section{Introduction}

The US National Aeronautics and Space Administration ("NASA") has already launched some online software that can predict or anticipate the impact on many cities of the world of the melting of glacier ${ }^{1}$ With this software, people can see how to predict the melting of a glacier into water that is globally distributed. This software offers-for every city-any configuration regarding icebergs, glaciers or ice peaks, which is absolutely crucial. Although Indonesia is far away from any area of ice mountains, this does not mean that it will not be impacted by the melting of a glacier at the North or South Pole. ${ }^{2}$ The melting of a glacier or ice mountain due to global warming has an impact on sea levels, and potentially causes islets or small islands across the surface of the earth to sink.

In September 2009, a great number of icefloes and icebergs coming from the Antarctic became visible floating in the waters around New Zealand, at a distance of $25 \mathrm{~km}$ from the coastline. Then, in October 2009, giant icebergs were discovered around Macquarie Island, Australia; some of these icebergs were $2 \mathrm{~km}$ wide and others were similar in size to the Olympic Stadium in Beijing known as the Bird's Nest stadium. ${ }^{3}$ In November 2009, satellite photos showed icebergs in great groups moving from the Antarctic across the area of Auckland Island, which lies around 450 $\mathrm{km}$ east of New Zealand. This event was published so that all the ships navigating in the area concerned might be careful because the existence of the icebergs could endanger navigation. ${ }^{4}$

A volcanic eruption occurred in the glacier area of Okjokull, Iceland on 4 April 2010. The volcanic dust that blew up, which reached a height of about $10 \mathrm{~km}$, polluted the air of a large number of European states in such a way that flying activities from and to the European continent had to be stopped for an unlimited time, since the volcanic dust endangered the aircraft. ${ }^{5}$ Iceland has been commemorating the loss of

1 E. Hardoko, NASA: Ice Four Cities in Indonesia are Threatened with Being Sunk [Es di KutubMencair, Empat Kota di Indonesia Terancam], BBC News (Indonesia), Nov. 20, 2017, available at https://internasional.kompas.com/ $\mathrm{read} / 2017 / 11 / 20 / 17584121 /$ nasa-es-di-kutub-mencair-empat-kota-di-indonesia-terancam?page=all.

2 Id.

3 M. Tran, Antarctic iceberg found floating near Macquarie island, GUARDIAN, Nov. 12, 2009, available at https://www. theguardian.com/world/2009/nov/12/antarctic-iceberg-floating-macquarie-island.

4 See Floating Ice Mountain Evacuated New Zealand [GunungEsTerapungHijrahkeSelandiaBaru], Kompas.com, Nov. 24, 2009, available at https://ekonomi.kompas.com/read/2009/11/24/04123493/gunung.es.terapung.hijrah.ke.selandia. baru; D. Irvine, Massive icebergs floating towards coast of New Zealand, CNN, Nov. 25, 2009, available at http:// edition.cnn.com/2009/TECH/science/11/25/iceberg.newzealand/index.html.

5 M. Mancini, Here's The Important Difference between Global Warming and Climate Change, Sciencealert.com (Sept. 
Okjokull, with the prime minister and guests from universities and the UN who were attending a ceremony at the site to highlight the urgency of climate change. ${ }^{6}$ Besides the volcanic dust blowing up from the eruption of the volcano, the glacier in the Okjokull area melted so that the surface of the rivers rose by 3 metres, which had an impact on the sea levels. ${ }^{7}$

Furthermore, in July 2010, an island within the Panama archipelago called Gardi Sugdub sank. ${ }^{8}$ The rise in sea level due to global warming forced thousands of the original inhabitants of Panama (Kuma ethnic group) to leave their habitat on the islands in the low-lying regions in this archipelagic state of the Caribbean. More irregular seasons, tornados and higher waves due to global warming made the island within the Panama archipelago sink. ${ }^{9}$

The events mentioned above, including the numerous icebergs moving from the Antarctic towards New Zealand, the volcanic eruption that melted the Okjokull glacier and the sinking of Gardi Sugdub Island, are due to rises in sea levels caused by global warming. In addition to having an impact on climate change, global warming has caused icebergs and iceshelves that had been in existence for thousands of years to melt. Without any international agenda to mitigate global warming, the process of melting icebergs will accelerate, causing sea levels to rise further. Sea-level rises of a few metres will threaten and potentially sink both island states and archipelagic states lying in the Indian and Pacific Oceans.

In Indonesia, the sea level will rise by between 0.5 and $0.7 \mathrm{~cm}$ a year for the territory of South Sumatra and the sea level by the year 2030 is projected to be between $6.15 \mathrm{~cm}$ and $13.5 \mathrm{~cm}$ higher than the level in the year $2000 .^{10}$ A short while ago, two islands in

22, 019), available at https://www.sciencealert.com/what-s-the-difference-between-global-warming-and-climatechange.

$6 \mathrm{Mvb} / \mathrm{Tj}$, Iceland holds ceremony for first glacier lost to climate change, AFP/AP, Aug.18, 2019, at A1, available at https://www.dw.com/en/iceland-holds-ceremony-for-first-glacier-lost-to-climate-change/a-50068489.

7 T. Luckhurst, Extinction of Glacier in Iceland Remarked with Epigraphy [Punahnyasebuahgletser di Islandia yang ditandaidenganprasasti], BBC News, Aug. 18, 2019, available at https://www.bbc.com/indonesia/majalah-49385319. See also A. Augesti, Unique Icelandic Residents Hold Burial of Glaciers Melt Due to Climate Change [Unik, WargaIslandiaGelarPemakamanGletser yang MencairAkibatPerubahanIklim], LiPuTAN6, Aug. 23, 2019, available at https://www.liputan6.com/global/read/4044944/unik-warga-islandia-gelar-pemakaman-gletser-yang-mencair-akibatperubahan-iklim.

8 S. Matteson, Rising Sea Drives Panama Islander to Mainland, ReuTERs, July 12, 2010, available at https://www.reuters. com/article/us-panama-climate-islands/rising-sea-drives-panama-islanders-to-mainland-idUSTRE66B0PL20100712. See also Displacement Solutions, Mission Report, One Step at a Time: The Relocation Process of The GardiSugdub Community in Gunayala, Panama 4-5 (Aug. 2015), available at http://displacementsolutions.org/wp-content/uploads/ 2015/07/One-Step-at-a-Time-the-Relocation-Process-of-the-Gardi-Sugdub-Community-In-Gunayala-Panama.pdf.

9 S. Mattson, Rising sea drives Panama islanders to mainland, ReUTERS, July 12, 2010, available at https://www.reuters. com/article/us-panama-climate-islands/rising-sea-drives-panama-islanders-to-mainland-idUSTRE66B0PL20100712.

10 National Geographic, Sinking of Indonesian Archipelago [TenggelamnyaKepulauan Indonesia] KomPasiana.COM, 
South Sumatra in the Indonesian Republic-Betet and Gundul ${ }^{11}$ - were between 1 and 3 metres underwater due to global warming or climate change. There are four other islands currently at a height of 4 metres above the sea surface that are threatened with sinking if significant measures are not taken by governments to mitigate the global warming. The four islands concerned are Bird Island (Pulau Burung), which is currently at almost the same level as the surface of the sea, Bat Island (Pulau Kalong) and Salah Namo Island (Pulau Salah Namo), both of which are 2 metres above sea level, and Sacred Island (Pulau Keramat), which is 3 metres above the sea surface. ${ }^{12}$

The Republic of Indonesia, as an archipelagic state and maritime country, ${ }^{13}$ will not be free from the possibility of the loss or sinking of thousands of islands, including some of the outermost small islands used as basepoints in drawing the archipelagic straight baselines. The replacement of the basepoints and archipelagic baselines must therefore be anticipated. According to German Watch, Indonesia is ranked third highest in terms of the risk of the impact of global warming. ${ }^{14}$ This is based on the occurrence of natural disasters related to climate change due to global warming. ${ }^{15}$

Global warming or climate change, like it or not, has become a highly debated issue in the last two decades, with its critical impacts on nature and the lives of human beings. One of these impacts is sea level rises, which bring particular challenges to coastal states. Sea level rises can theoretically cause the submergence of lowland areas, which is harmful to habitats and human populations living in these areas. Coastal areas are also vulnerable to storm surges resulting from more extreme weather events. ${ }^{16}$ For small islands, sea level rises are a serious threat, which can shift

Sept. 5, 2017, available at https://www.kompasiana.com/teguhxhsabs/59aeb3f23a327218cf33a682/tenggelamnyakepulauan-indonesia.

11 R. Gunadha \& H. Rahmayunita, Two Islands in Sumatra Vanish Immersed, Four others Threatened to follow [DuaPulau di Sumatera LenyapTenggelam, EmpatLainnyaTerancamMenyusul], SuARA.com, Jan. 21, 2020, available at https:// www.suara.com/news/2020/01/21/135450/dua-pulau-di-sumatera-lenyap-tenggelam-empat-lainnya-terancammenyusul.

12 Id. at 2.

13 Pub. Inst. Hasanuddin Univ. [LembagaPenerbitanUniversitasHasanuddin], The Policy Framework for Developing the Main Scientific Pattern of Hasanuddin University [KerangkaKebijakanPengembanganPolaIlmiahPokok UniversitasHasanuddin], 14 Lephas Press Makassar, May 31, 1999.

14 German Watch, Climate Change Performance Index, available at https://www.climate-change-performance-index. org.

15 J. Gabbatish, Natural Disasters Increasingly Linked to Climate Change, New Report Warns, InDEPEndent, Dec. 11, 2017, available at https:/www.independent.co.uk/environment/climate-change-natural-disasters-link-increase-globalwarming-report-warning-a8103556.html.

16 A. Arsana, The Sinking of Sovereignty and Sovereign Rights? Mitigating the Impacts of Climate Change to Maritime Jurisdiction and a Proposal for Solutions, 3(2) Indon. L. REv.125-7 (2013). 
the coastline landward, thereby shrinking the land. An extreme sea level rise can not only decrease the size of the land, but also totally submerge a small island. ${ }^{17}$

The primary purpose of this research is to analyse the relationship between global warming and the submergence of some Indonesia's outermost islands. It will also analyze the possibility of replacing certain basepoints and archipelagic baselines for the sinking of some of the outermost islands. ${ }^{18}$ This paper is composed to four parts including Introduction and Conclusion. Part two will discuss the global warming and the outmost Indonesian Island sinking. Part three will search for the measures for mitigating the impact of global warming.

\section{Global Warming and the Outermost Indonesian Islands Sinking}

Global warming generally refers to the observed warming of the planet due to human-caused greenhouse gas emissions, while climate change generally refers to all the different long-term changes in our climate, including sea level rises, extreme weather and ocean acidification. ${ }^{19}$ Although people tend to use these terms interchangeably, global warming is just one aspect of climate change. Global warming and climate change-while closely related and sometimes used interchangeably technically refer to two different things ${ }^{20}$ : climate change is generally considered a "more scientifically accurate term" than global warming. NASA explained in 2008 that "[c] hanges to precipitation patterns and sea levels are likely to have a much greater human impact than higher temperatures alone." ${ }^{21}$ When considering all the impacts scientists have observed in recent decades - including the acidifying ocean, worsening wildfires and more intense deluges-climate scientists are likely to continue to favour

17 Id. at 125.

18 Archipelagic baselines are regulated in Article 47 of the UNCLOS and implemented in various national pieces of legislation of the Indonesian state, such as the Law of the Indonesian Republic Number 6 Year 1996 (regarding Indonesian waters) and Government Regulation Number 38 Year 2002 (regarding the geographical coordinate list of basepoints of archipelagic baselines).

19 J. Romm, Is there a difference between global warming and climate change?, 2020 The Years Project, available at https://theyearsproject.com/ask-joe/difference-global-warming-climate-change.

20 See What's the Difference between Global Warming and Climate Change?, Climate Reality Project (Oct. 26, 2016), available at https:/www.climaterealityproject.org/blog/difference-between-global-warming-and-climate-change. See also P. Wright, What's the Difference Between Global Warming and Climate Change?, Weather Channel, July 27, 2017, available at https:/weather.com/science/environment/news/climate-change-global-warming-difference.

$21 \quad$ Id. See also Romm, supra note 19. 
the term climate change. In general or popular usage, global warming and climate change have become interchangeable over the past few decades, and the trends of global warming and climate change are likely to continue this century, especially as the warming itself becomes more and more serious nowadays prominent. ${ }^{22}$

Global warming acts as a trigger for the occurrence of events that are detrimental to both the environment and various sectors of human life, ${ }^{23}$ such as global sea level rises caused by the melting of ice at the North and South Poles. The rises in sea level threaten the socio-economic life of coastal societies and could result in a number of islets sinking below the surface of the sea. The mass media also report that a lake in Chile suddenly disappeared because an ice buttress, which acted as a dam for the lake, melted. ${ }^{24}$ Indonesia, as a state located on the Equator, has suffered some impacts of climate change and global warming. For example, rising sea levels have placed some Indonesian islands in threatened or dangerous situations. Apart from global warming, the arbitrary exploitation of resources by communities endangers some islands and puts them at risk of sinking. ${ }^{25}$ Indonesia should avoid the arbitrary exploitation of resources, since its territory consists of 17,508 islands. Arbitrary exploitation could put some of its outermost islands in danger of sinking, which will bring about the replacement of basepoints and straight archipelagic baselines.

Climate change or anomalies will have a dramatic impact on the islands of Indonesia. An example is Bali Island, which is $5,632 \mathrm{~km}^{2}$ in width area. ${ }^{26}$ It is predicted that, in 2050, Bali Island will be submerged in water to the extent of $489 \mathrm{~km}^{2}$. However, by 2070, the area sinking below the surface will be greater, at up to 557 $\mathrm{km}^{2}{ }^{27}$ The submersion of this area will result in Bali Island being separated into two parts. The Genting area (Tanah Genting), which thus far has connected the greater part of Bali Island with Nusa Dua, will sink. Nusa Dua will become an individual island, separate from Bali Island. ${ }^{28}$ Tembora Island has an extent of 200 hectares, but

22 Id.

23 M. Denchak, Are the Effects of Global Warming Really that Bad? March 15, 2016, available at https://www.nrdc. org/stories/are-effects-global-warming-really-bad.

24 A lake in Cile suddenly disappeared. Waters within the lake are finished because they poured into the river after the natural dike in form of the eternal ice buttress surrounding the dike melted caused by the global warming See MBS, The Lake Disappeared Due to Global Warming [DanauHilangAkibatPemanasan Global], OKeTeChNo, Apr. 13, 2008, available at $\mathrm{https}$ //techno.okezone.com/read/2008/04/13/56/100102/danau-hilang-akibat-pemanasan-global.

25 S. Lahitani, The Islands in Indonesia are Threatened with Sinking [Pulau-pulau di Indonesia TerancamTenggelam], Liputan6, Dec. 17, 2014, available at https://www.liputan6.com/citizen6/read/2148354/pulau-pulau-di-indonesiaterancam-tenggelam.

26 Id. at 2.

27 Id.

28 T. Maulidan, Sinking of Indonesian Archipelago [TenggelamnyaKepulauan Indonesia], KomaPASIANA.Com, Sept. 5, 
this island is in danger of sinking because of bauxite-related activities. The outermost lines of this island can still be seen, but it is now underwater so the area of this island was originally greater than it currently is. ${ }^{29}$

Nipah Island (Pulau Nipah), which is located in the province of Riau archipelago, is an outermost small island without inhabitants. This island, directly adjacent to Singapore, is threatened with sinking due to sand mining, as well as the rising sea level. Fortunately, the Indonesian government has been successfully revitalizing and rehabilitating the alarming condition of Nipah Island; unless the condition of this island is improved, the Indonesian Republic will lose one of its outermost islands. This would mean that the Indonesian Republic loses one basepoint, which would potentially result in a dispute over sovereignty regarding a very strategic island, given the position of Nipah Island as one of the outermost islands used as a basepoint for the archipelagic straight baselines of Indonesia. ${ }^{30}$

Sentut Island is an outermost Indonesian island ${ }^{31}$ that lies within the area of the South China Sea, as well as the boundary area between Indonesia and Malaysia. Sentut Island lies east of Bintan Island (Pulau Bintan), and is less than 2 hectares in area. Currently, the breadth and height of the island are decreasing because of erosion abrasion and the exploitation of bauxite, which is ultimately carried out by a national company called Gunung Sion company Ltd. In addition, the island is threatened by sinking, although the company is no longer operating there ${ }^{32}$ If Sentut Island disappears or sinks, Indonesia will lose a strategic outermost island and one of the straight archipelagic baselines will shift. In this case, Indonesia should replace the basepoint and the straight archipelagic baseline.

The National Geographic Society of Indonesia predicted in 2011 that Kelor Island would sink about 45 years after that date. ${ }^{33}$ This prediction is based on data coming from UPT Taman Arkeologi Onrust, which show that in the 1980s Kelor Island had

2017, available at https:/www.kompasiana.com/teguhxhsabs/59aeb3f23a327218cf33a682/tenggelamnya-kepulauanindonesia.

29 Id. at 2.

30 M. Hendrapati, Mapping of the Indonesian Archipelagic Baseline [Bunga Rampai Hukum Laut Internasional] 119 (Pustaka Pena Press, 2015).

31 Regulation of Indonesian Government No. 38 Year 2002 Regarding the Geographical Coordinate List of Basepoints for the Straight Archipelagic Baselines, Government Official Gazette 2002/72. Additional Government Official Gazette of Indonesian Republic 1211.

32 See 4 Indonesian Islands in Danger of Being Lost and Sinking [4 Pulau di Indonesia iniTerancamHilangdanTenggelam], Kompasiana.COM, Aug. 28, 2015, available at https://www.kompasiana.com/yayasanaksicepattanggap/55dfe27371937 3dc122bd792/4-pulau-di-indonesia-ini-terancam-hilang-dan-tenggelam.

33 Alamendah, Kelor Island Will Sink [PulauKelor Akan Tenggelam], Alamendah's Blog (May 14, 2011), available at https://alamendah.org/2011/05/14/pulau-kelor-akan-tenggelam. See also Lahitani, supra note 25. 
an area of 1.5 hectares, but nowadays its area is less than 1 hectare. This reduction has been caused by abrasion and the rise in the sea level due to global warming. ${ }^{34}$

Padang Island, which is located in the Province of Riau, is in danger of sinking, because the forest in an area of peat moss is continuously being made into an acacia plantation by a forestry company. The submerged peat moss swamp has pores, like a sponge made of foam rubber. The clearing of the forest in the peat moss area and the construction of a canal by the company will reduce and drain the water and carbon contained in the peat moss, with the result that area of peat moss will be decreasing decrease. $^{35}$

In fact, many islands in Indonesia are still in danger of sinking. As an archipelagic state, Indonesia faces a real threat relating to the rise in sea levels due to global warming or climate change. It is estimated that by 2050 about 1,500 islands in Indonesia will have sunk because of the rise in sea levels. ${ }^{36}$ Unless the current approach is changed soon, not only those islands mentioned above will sink and disappear from the Indonesian national map, but also the Indonesian territory will be decreasing reduced. ${ }^{37}$

It is predicted that Indonesia will lose roughly 2,000 islands by the year 2030, according to Witoelar (a former Minister for Life Environment Affairs under former President Suharto) who has said that Indonesia could lose 2,000 of its islands by 2030 if sea levels continue to rise. ${ }^{38}$ The cost would be very high, since it is not just about building better infrastructure, but we would have to relocate people and change the way people live. If no effort is made by the international community and the Indonesian government itself, ${ }^{39}$ in particular, around 2,000 of the outermost islands of

34 See PulauKelor (KepulauanSeribu) Will Be Sinking, Nation Developer, May 21, 2011, available at https:// nationdeveloper.wordpress.com/2011/05/21/pulau-kelor-kepulauan-seribu-akan-tenggelam.

35 Supra note 26, at 3. See also Pklbptik, 5 Indonesian Islands Threatened to Sink [5 Pulau Di Indonesia yang Terancam Tenggelam], BAGIInFormasi, July 20, 2016, available at http://blog.unnes.ac.id/syaifullah/2016/07/20/5-pulau-diindonesia-yang-terancam-tenggelam; Kelor Island will be Sinking (Pulau Kelor Akan Tenggelam), Alamendah's Blog (May 14, 2011), available at https://alamendah.org/2011/05/14/pulau-kelor-akan-tenggelam.

36 See Indonesia: Rising sea 'threatens 1,500 islands,' BBC News, Feb. 25, 2014, available at https://www.bbc.com/ news/blogs-news-from-elsewhere-26337723.

37 Zubaidah Nazeer, Indonesia risks losing up to 1,500 islands by 2050, DAWN, Feb. 25, 2014, available at https://www. dawn.com/news/1089367. See also E. Burhaini Faizal, Rising sea levels threaten 2,000 islands in Indonesia, JAKARTA Post, Dec.17, 2015, at A1, available at https://www.thejakartapost.com/news/2015/12/17/rising-sea-levels-threaten2000-islands-indonesia.html.

38 E. Burhaini Faizal, Rising sea levels threaten 2,000 islands in Indonesia, JAKARTA Post, Dec.17, 2015, at A1, available at https://www.thejakartapost.com/news/2015/12/17/rising-sea-levels-threaten-2000-islands-indonesia.html.

39 The Bali conference is aimed at finding a successor to the Kyoto Protocol, which expires in 2012, on cutting climate warming carbon emissions. With over 17,000 islands, many at risk of being washed away, Indonesians are anxious to see an agreement reached and quickly implemented that will keep rising seas at bay. See S. Katyal \& A. Arga, Climate Change May Wipe Some Indonesian Islands Off Map, Reuters, Dec. 3, 2007, available at https://www. 
Indonesia will inevitably be sinking. These islands have been used as the basepoints in drawing straight archipelagic baselines, which is one of the main methods to record maritime boundaries and ultimately the existence of the Indonesian Republic as an archipelagic state. The loss of those outermost islands will certainly require the replacement of basepoints and archipelagic straight baselines. ${ }^{40}$ Sea level rise can also change the legal status of insular features (small islands/rocks and low tide elevation) that will also affect their capacity in making maritime claim. For an archipelagic State like Indonesia, small outer islands/rocks or low-tide elevation are important for location of basepoints forming the entire system of archipelagic baselines.

The configuration of the Indonesian archipelagic state, where the archipelago is shaped like the kuda lumping horse that is acknowledged in the cultural art of the Javanese community, may potentially remain only as a memory if the emission of greenhouse effects cannot be mitigated by international treaty. This configuration cannot be separated from, and has to be seen in the context of, the United Nations Convention on the Law of the Sea 1982 ("UNCLOS") ${ }^{41}$ and the Indonesian national legislation, which stipulate that the drawing of archipelagic straight baselines must not depart to any appreciable extent from the general configuration of the archipelago. $^{42}$ The configuration created through the straight archipelagic baselines, which are used in turn with the other baselines, does not depart to any appreciable extent from the general configuration of Indonesia's archipelagic territory, since when this configuration is observed accurately, it appears similar to that of a kuda lumping horse, which is a very famous piece of Javanese culture. The drawing or photo of kuda lumping horse is familiar with totality of the archipelagic baselines which embrace straight archipelagic baselines utilized in turn with normal and straight baselines. The totality of archipelagic baselines surround all the archipelagos of Indonesia, which is proven with Indonesian map. Global warming has the potential to sink and eliminate thousands of islands from the world map, including many of the outermost islands of Indonesia. It may destroy the configuration of the archipelagic territory of Indonesia and, furthermore, its existence as an archipelagic state. As a consequence, both the international community in general, and Indonesia

reuters.com/article/us-climate-indonesia-islands/climate-change-may-wipe-some-indonesian-islands-off-mapidUSJAK15507820071203.

40 A. Arsana, The Sinking of Sovereignty and Sovereign Rights? Mitigating the Impacts of Climate Change to Maritime Jurisdiction and a Proposal for Solutions, May 2014, available at https://www.researchgate.net/publication/287437715_ The_Sinking_of_Sovereignty_and_Sovereign_Rights_Mitigating_the_Impacts_of_Climate_Change_to_Maritime_ Jurisdiction_and_a_Proposal_for_Solutions.

41 UNCLOS art. 47(1-3).

42 Law No. 6 Year 1996 art. 3(3). 
in particular, should take measures to overcome the polluting and damaging effects of greenhouse gases in the atmosphere, which are the main cause of global warming. This situation must be dealt with in advance to prevent the replacement of the basepoints and archipelagic baselines. ${ }^{43}$

\section{Measures for Mitigating the Impact of Global Warming or Climate Change}

\section{A. Paris Climate Agreement}

On December 12, 2015, nearly 200 states adopted the Paris Agreement of the United Nations Framework Convention on Climate Change ("UNFCCC") (hereinafter the Paris Climate Agreement), which was the first global treaty aimed at slowing down global warming. ${ }^{44}$ The UNFCCC proclaimed to the nations of the world the need to both reduce and eradicate any pollution from greenhouse gases, although the Paris Climate Agreement does not identify sanctions for any states creating such pollution. ${ }^{45}$ The Paris Climate Agreement contains provisions regarding the Nationally Determined Contributions ("NDCs") that were expected to be implemented in the year 2020. In preventing climate change from having an impact on the global agenda, an international framework for cooperation is needed to overcome the global issue of climate change due to global warming. ${ }^{46}$

Nearly 200 countries reached a consensus in Paris on the need to cut greenhouse gas emissions, so that many observers regarded the consensus as an achievement in itself and hailed it as historic event. Before the consensus or the Paris Climate Agreement, the Kyoto Protocol of 1997 set emission cutting targets for a handful of

43 UNCLOS art. 47 and national legislation of Indonesia (Law Number 6 of Year 1996 and Government Regulation No. 38 Year 2002) enable a configuration of the Indonesian archipelagic state, based on archipelagic straight baselines, that is similar to the figure of kuda lumping horse, which is very famous in the cultural art of Java. We first encountered this idea more than thirty years ago when we attended a lecture given by Prof. Munajat Danusaputro.

44 Paris Climate Agreement 2015, available at https://unfccc.int/process-and-meetings/the-paris-agreement/the-parisagreement.

45 B. Chappell, Nearly 200 Nations Adopt Climate Agreement at COP21 Talks In Paris, NPR (Dec. 12, 2015), available at https://www.npr.org/sections/thetwo-way/2015/12/12/459464621/final-draft-of-world-climate-agreement-goes-to-avote-in-paris-saturday.

46 Law No. 16 Year 2016, Oct. 25, 2016. Undang-UndangNomor 16 Tahun 2016 tentangratifikiasiatasPersetujuan Paris terhadapKonvensiKerangkaKerja PBB mengenaiPerubahanIklim [State Gazette of Indonesian Republic 2016/204. Additional Gazette of State No. 5939. Law Number 16 Year 2016 regarding Ratification of Paris Agreement to United Nations Framework Convention on Climate Change], available at https://www.bphn.go.id/data/documents/16uu016.pdf. 
developed countries, but the US pulled out and others failed to comply. However, scientists point out that the Paris Climate Agreement must be stepped up or implemented by the states ratifying it if they want to curb dangerous climate change. The agreement lays out a roadmap for speeding up progress in reducing global temperatures rise as much as $2.7^{\circ} \mathrm{C}$, so that the agreement has such purposes: 1) to keep global temperatures "well below" $2.0^{\circ} \mathrm{C}\left(3.6^{\circ} \mathrm{F}\right)$ above pre-industrial times and "endeavour to limit" them even more, to $1.5^{\circ} \mathrm{C} ; 2$ ) to limit the amount of greenhouse gases emitted by human activity to the same levels that trees, soil and oceans can absorb naturally, beginning at some point between 2050 and 2100; 3) to review each country's contribution to cutting emissions every five years so they scale up to the challenge; 4) for rich countries to help poorer nations by providing "climate finance" to adapt to climate change and switch to renewable energy. ${ }^{47}$

President Joko Widodo, at COP 21 in Paris, made a commitment that Indonesia would reduce emissions by 29 per cent from "Business as Usual," in a statement supporting the Paris Climate Agreement. ${ }^{48}$ In order to achieve the purpose of the Paris Climate Agreement the nations have to mitigate or reduce their emission of greenhouse gases within the next half century, so that less pollution is absorbed and neutralized by the environment. In front of the world leaders, Joko Widodo said that climate change mitigation should involve indigenous people. His statement was important for Indonesia, because indigenous communities have made significant contributions to reducing carbon emissions and promoting natural conservation. ${ }^{49}$

\section{B. United States}

President Trump has begun withdrawing the US from the Paris Climate Agreement, which was signed by nearly all nations to reduce fossil fuel emissions. Trump replaced Obama's Clean Power Plan, which had been intended to bring about a sharp reduction in emissions from the US power plants. He took the first step to weaken fuel economy standards for cars, which had been the single most important measure

47 H. Briggs, What is in the Paris climate agreement, BBC News, May 31, 2017, available at https://www.bbc.com/news/ science-environment-35073297.

48 A. Setiawan, President Jokowi: Indonesia Commits Reducing Emission by 29\%, Cabinet Secretariat of the Republic of Indonesia (Dec. 1, 2015), available at https://setkab.go.id/en/president-jokowi-indonesia-commits-reducingemission-by-29. See also S. Wiradji, Focus Issue: Indonesia aims to drive growth of clean energy but challenges remain, JAKARTA POST, Oct 24, 2018, at A1, available at https:/www.thejakartapost.com/news/2018/10/24/focus-issueindonesia-aims-drive-growth-clean-energy-challenges-remain.html.

49 W. Septiawan, Indigenous people welcome Jokowi's climate speech, JAKARTA Post, Dec. 2, 2015, available at https:// www.thejakartapost.com/news/2015/12/02/indigenous-people-welcome-jokowis-climate-speech.html. 
to rein in the largest source of the US emissions emission. ${ }^{50}$ In the latest volume of the National Climate Assessment, American scientists revealed much about the robust, sobering scientific consensus on climate change. ${ }^{51}$ They also revealed a sharp controversy between President Donald Trump and 13 federal agencies, because Trump has rejected the central findings of the assessment that emissions of carbon dioxide are caused by human activities, are already causing lasting economic damage, and have to be brought rapidly to zero. ${ }^{52}$ According to Trump's cabinet, the report by the National Climate Assessment institution is overreaching or exaggerated, with the result that it must be rejected.

The EU has proclaimed a long-term goal to combat and eradicate climate change globally. In forming a strategy for this goal, a group of 28 states is targeted, which has a global contribution of 10 per cent of greenhouse gas emissions, to make no emissions of greenhouse gases by $2050 .^{53}$ To achieve this target, the EU will offer guidelines for every state, company and society on planning expenditure for reducing global warming. ${ }^{54}$ According to Miguel Arias Canete, a member of the Commission on Climate and Energy, the EU member states will, through this programme, be the first main economies to reduce their emission of greenhouse gases to 0 percent by the year $2050 .^{55}$ He says that it is important for the states of the world to have the long-term target stipulated in the Paris Climate Agreement regarding climate change, and that this target will be achieved through recently developed technology support. $^{56}$ The EU has demonstrated that it really respects the targets stipulated in the

50 S. Feldman \& M. Lavelle, Donald Trump's Record on Climate Change, Inside Climate News, Jan. 2, 2020, available at https:/insideclimatenews.org/news/19122019/trump-climate-policy-record-rollback-fossil-energy-history-candidateprofile.

$51 \quad I d$.

52 Id.

53 D. Tari, Europe Persisted in Endeavouring Prevention of Global Warming [EropaTetapUpayakanPencegahan PemanasanGlobal], KABAR24 (Nov. 28, 2018), available at https://kabar24.bisnis.com/read/20181128/19/864187/ eropa-tetap-upayakan-pencegahan-pemanasan-global.

54 A. Neves et al., The Covenant of Mayors For Climate and Energy Report Guidelines, EU Science Hub LD-NA-28160EN-N (2016), available at https://ec.europa.eu/jrc/en/publication/covenant-mayors-climate-and-energy-reportingguidelines. See also Communication from the Commission to the European Parliament, the European Council, the Council, the European Economic and Social Committee, and the Committee of the Regions, Brussels, Dec. 11, 2019 COM (2019) 640 final, available at https://ec.europa.eu/info/sites/info/files/european-green-deal-communication en.pdf. This Communication sets out a European Green Deal for the European Union (EU) and its citizens. It aims to transform the EU into a fair and prosperous society, with a modern, resource-efficient, and competitive economy where there are no net emissions of greenhouse gases in 2050 and where economic growth is decoupled from resource use.

55 Id. at 2. See also M. Strauss, EU Unveils Plan to Cut Emissions to Zero, in Bid to Save Planet, Bloomberg, Nov. 28, 2018, available at https:/www.bloomberg.com/news/articles/2018-11-28/eu-adopts-long-term-climate-plan-in-bid-tolead-ambitious-action.

56 Id. 
Paris Climate Agreement, even though Trump has decided to take the US out of the Agreement. $^{57}$

The EU also has a target to reduce the emission of greenhouse gases by at least 40 per cent in a decade. Although this target does not achieve what is required by the Paris Climate Agreement, which is to maintain a global temperature growth of under $2^{\circ} \mathrm{C}$, some scientists assert that any measures for preventing such damage due to global warming must be taken. ${ }^{58}$

\section{Indonesia}

Indonesia needs to take certain measures to mitigate global warming and its potentially disastrous impacts, especially the threat to the existence of the basepoints and straight archipelagic baselines. These basepoints and straight archipelagic baselines are the bases for the designation of Indonesia as an archipelagic state. In this regard, the statement of the former president of the Indonesian Republic, Susilo Bambang Yudhoyono, during the United Nations Summit on Climate Change 2009 in Copenhagen should be used as a guideline. ${ }^{59}$ He encouraged all groups to put aside their problems with each other in such a way that there might be a space to achieve maximum consensus and cooperation. ${ }^{60}$ Indonesia hopes to become a part of the global solution, especially in the issue of climate change. Indonesia wants to tackle the climate change issue effectively, including addressing the rising sea levels and the other consequences of global warming, mainly the sinking of the outermost islands. This could be done by, inter alia, voluntarily trying to lessen the emission of greenhouse gases by as much as 26 percent by 2020 or 41 percent by 2050, if Indonesia obtains foreign aid in the form of technology transfer or financial aid for adapting to and mitigating climate change. ${ }^{61}$ The Indonesian government expects that foreign aid in the form of technology transfer will help it to conduct measures for voluntarily

57 L. Friedman, Trump Serves Notice to Quit Paris Climate Agreement, N.Y. Times, Nov. 4, 2019, available at https:// www.nytimes.com/2019/11/04/climate/trump-paris-agreement-climate.html.

58 The EU's NDC under the Paris Climate Agreement is to reduce greenhouse gas emissions by at least $40 \%$ by 2030 compared to 1990, under its wider 2030 Climate And Energy Framework. For details, see EU, Climate Action: Paris Agreement, available at $\mathrm{https}: / /$ ec.europa.eu/clima/policies/international/negotiations/paris_en.

59 UNFCCC COP 15, International Calls For Action, available at https://unfccc.int/process/conferences/pastconferences/ copenhagen-climate-change-conference-december-2009/statements-and-resources/International-calls-for-action.

$60 \quad I d$.

61 Indonesia has played an active role in various international negotiations on climate change, and was the host of the 13th Conference of the Parties to the UNFCCC in Bali, which generated the Bali Action Plan. As one of the countries Indonesia is most vulnerable to the impacts of climate change. See I. Sofian et al., Indonesia Climate Change Sectoral Roadmap-ICCSR Synthesis Report (Dec. 2009), available at https://www.adaptation-undp.org/sites/default/files/ downloads/indonesia_climate_change_sectoral_roadmap_iccsr.pdf. 
reducing the emission of greenhouse gases to the levels mentioned above. Such measures would be taken through multilateral treaties, regional treaties, bilateral agreements, national legislation and local regulations.

If Indonesia wants to reduce the emission of greenhouse gases by as much as 26 percentage points by 2020, it must be more serious about committing to any concrete measures or the achievement of the target that was voluntarily prescribed. Technologies designed to lower energy consumption and eliminate the burning or use of fossil fuels are required. ${ }^{62}$

Indonesia signed the Paris Climate Agreement on April 22, 2016. ${ }^{63}$ On October 24, 2016, Indonesia ratified the Agreement through the enactment of Law Number 16 of 2016 regarding the Paris Climate Agreement, which was approved by the People's Representative Council. This ratification, as a commitment by the Indonesian Republic to mitigating or reducing carbon emissions and overcoming global warming or climate change, ${ }^{64}$ must be established through law, since the substance of the Paris Climate Agreement is global warming within the domain of the living environment, which has to be regulated by law. Climate change has an impact on the daily life of humankind, which will occur more quickly unless efforts are made by all the countries in the world. This includes Indonesia, a country with a large number of islands and the second longest coastline in the world. Indonesia must respond quickly to climate change, since the Indonesian territory consists of many islands which are separated by seas which control two-thirds of its territory. If the sea area is affected, the islands will also be threatened quickly. This view was stated by the Coordinating Minister for Maritime Affairs, Luhut Binsar Pandjaitan, when speaking in Jakarta in mid-July 2019. According to him, Indonesia, together with the other archipelagic and island states in the world, must be committed to addressing climate change. ${ }^{65}$ It is necessary to mitigate the potential of Indonesia's existing policies for land use and in the energy sector to prevent the emission reduction targets which should be achieved, since these areas together account for 80 percent of Indonesia's

62 Roof Insulation, Global Warming and Climate Change, Feb. 4, 2018, available at https://roofinsulations.co.za/globalwarming-climate-change.

63 X. Jiang \& J. Zhang, China's Legislative Practices on Climate Change after the Paris Agreement,10 J. EAST AsIA \& INT'L. L. 259 (2017).

64 See Ratification to Paris Agreement, a Commitment of all States Parties is Needed [Ratifikasikesepakatan Paris, 'komitmensemuapihakdibutuhkan], BBC News (Indonesia), Oct. 20, 2016, available at https://www.bbc.com/ indonesia/ indonesia/2016/10/161019_indonesia_dpr_ratifikasi_paris.

65 M. Ambari, Archipelagic and island states/AIS must be stuck together to face the impact of climate change [Negara KepulauanHarusBersatuHadapiDampakPerubahanIklim], MongaBAY, Aug. 12, 2019, available at https://www. mongabay.co.id/2019/08/12/negara-kepulauan-harus-bersatu-hadapi-dampak-perubahan-iklim. 
emissions. ${ }^{66}$ Indonesia can meet its emissions targets if it strengthens its existing policies. By increasing its commitment from a 29 percent reduction to a 41 percent reduction by 2030 as its NDC, Indonesia has stepped up its efforts against climate change. The 2015-2019 National Development Planning Document set out several climate mitigation and adaptation targets, ${ }^{67}$ which were translated into domestic targets for climate action. The Indonesian government has increased its budgets for climate mitigation and adaptation efforts, as well as introducing fiscal policies to reduce emissions from energy and land use.

The Indonesian government must adopt and enforce laws and socialize the impact of climate change among the people of Indonesia. It should pay more attention to the people or companies whose activities are causing climate change, such as deforestation, forest burning, illegal logging, disposal of industrial waste and plastic pollution. Indonesian people should be taught to minimize the use of plastics. Also, gas emissions from vehicles should be reduced as much as possible. People should be encouraged not to use their cars and motorcycles every day and to use public transport and bicycles. All these need to be regulated by the federal government of Indonesia and implemented by all the local governments.

\section{Conclusion}

There is a close relationship between the emission of greenhouse gases, global warming, climate change, the increase of marine surface temperatures, the melting of ice mountains in the Arctic and Antarctic areas, and the loss or sinking of thousands of islands from the world map, including the outermost small islands of Indonesia. Sentut Island and Nipah Island, as outermost islands, may sink, so that anticipating the replacement of basepoints is essential. Some time ago, Betet Beten Island and Gundul Island became submerged to between 1 and 3 metres below the marine surface. Although these two islands are not outermost islands, we have to prevent, or at least anticipate, the outermost islands adjacent to those islands sinking.

Compared with the Copenhagen Accord which has no binding force, the Paris Climate Agreement is binding on the states ratifying it. The ratification of the Paris Climate Agreement by the Indonesian Republic through Law Number 16 of 2016

66 H. Chrysolite et al., Evaluating Indonesia's Progress on its Climate Commitments, World Research Institute (Oct. 4, 2017), available at https://www.wri.org/blog/2017/10/evaluating-indonesias-progress-its-climate-commitments.

67 Id. 
indicates a strong commitment to mitigating global warming and climate change due to greenhouse effects. This institutional effort can mitigate the greenhouse effects that result in the sinking of the outermost islands. Practical measures are needed to realize this target, such as the enforcement of laws. Besides, this national policy should be incorporated into various programmes and action plans that are institutionalized in an act or government regulation. All laws should address, inter alia, aspects of global warming, such as scope, causes and effects, responsibility and liability, legal enforcement, sanctions, etc. All these aspects should be directed to realizing the achievement of the individual and voluntary mitigation target for greenhouse gas emissions in such a way that these measures contribute to anticipating and preventing the sinking of any small outermost islands and the replacement of any archipelagic baselines. 


\section{Annex 1: Peta NKRI is familiar with Kuda Lumping Horse}

PETA NEGARA KESATUAN REPUBLIK INDONESIA

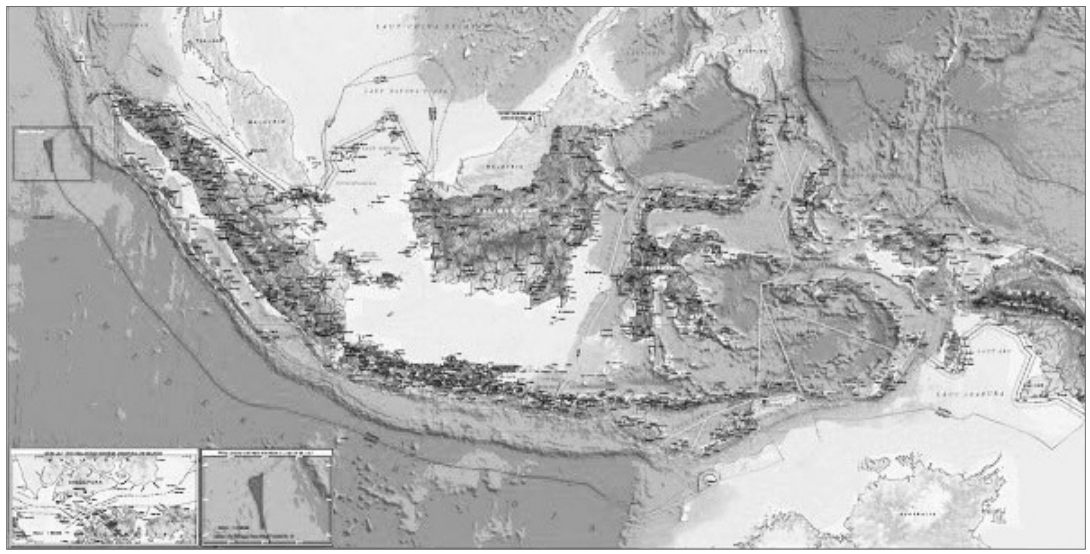

Source: Peta NKRI versi terbaru kini dapat diunduh di Ina-Geoportal [The latest version of the Homeland Map can now be downloaded at Ina-Geoportal], available at http://irmangenotip.blogspot.com/ 2017/07/indonesia-punya-peta-baru-ini.html

Annex 2: Peta Pulau Nipa

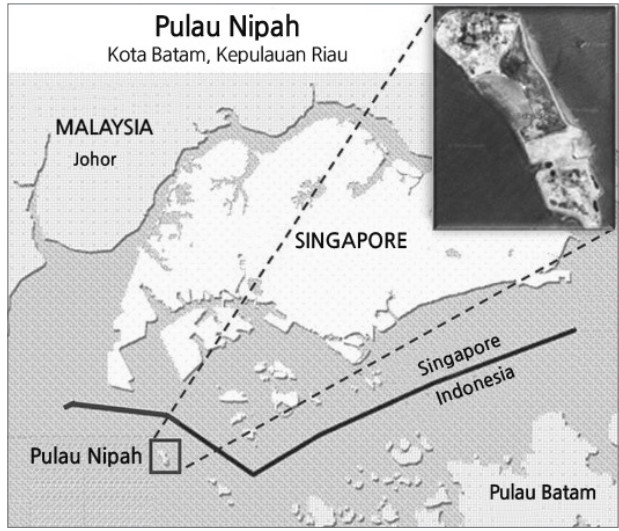

Source: Pulau Nipah; Patok Negara Yang Pernah Nyaris Lenyap [Nipah Island; State Stakes That Never Almost Disappeared], available at https://hendrajailani.blogspot.com/2019/08/pulau-nipahpatok-negara-yang-pernah.html. 


\section{Annex 3: Sentut Island in Natuna Archipelago \\ (Peta Pulau Sentut di Kepulauan Natuna)}

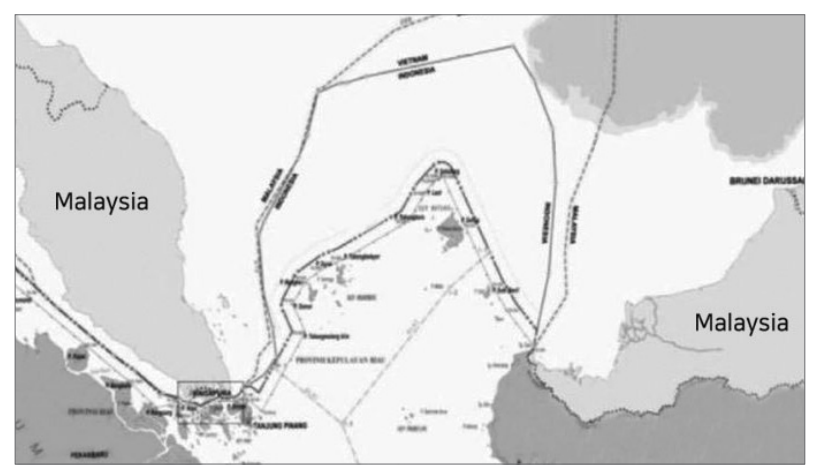

Source: Ini Kronologis RI Protes Keras Klaim China Soal Natuna [This is the Chronology of the Republic of Indonesia Strongly Protests China's Claim on Natuna], CNBC (Indonesia), Jan. 4, 2020, available at https://www.kompasiana.com/fadlirakhmad/56572610f59673c409abb802/kepri-bukanriau-bincang-santai-blogger-kompasianer-dengan-kadispar-kepri.

Annex 4: Betet Island and Gundul Island which Sank (Peta Pulau Betet dan Pulau Gundul yang sudah tenggelam)

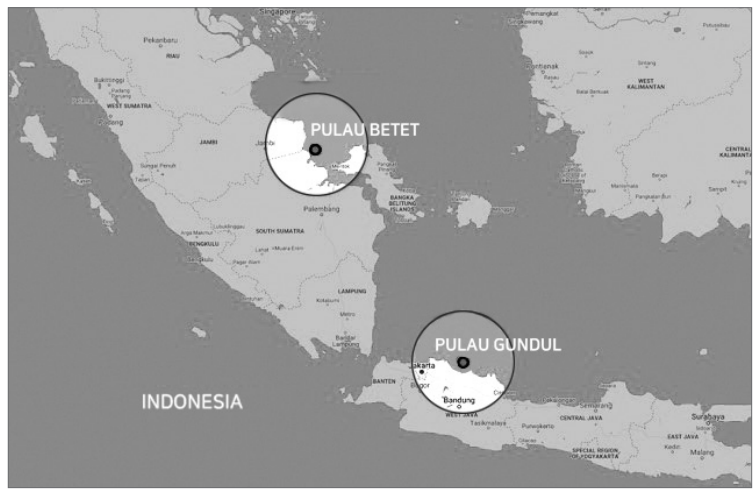

Source: Peta Pulau Betet dan Pulau Gundul yang sudah tenggelam di Provinsi Sumatera Selatan [Map of Betet Island and Gundul Island that have sunk in South Sumatra Province], available at https:// berita55.com/read-epaper/read/21-01-2020/dua-pulau-di-sumatera-selatan-tenggelam-empatlainnya-terancam. 